\title{
Chilean Public Policies and their Impact on Biotechnology Small and Medium Enterprises
}

\begin{abstract}
It is difficult to find cases of technology-based Small and Medium Enterprises in developing countries, however Chile has some within the biotechnology sector. How has this been possible? As a consequence of the different public policies and structural economic conditions that allowed their emergence, especially in the 1990s. This study describes the historical conditions and how they have been able to create a sector within the Chilean economy. From the analysis of secondary data the emergence of this type of company within the country is described. This analysis shows the link between structural conditions and appropriate public policies, meaning that these companies did not emerge by chance. Understanding their development process is crucial to promote the creation of more such technologybased Small and Medium Enterprises, as they have many positive externalities and are more globally competitive.
\end{abstract}

Keywords: Chilean SMEs; biotechnology; innovation; scientific public policies; entrepreneurship; Chile

Corresponding author: e-mail: isabel.torres@ usach.cl

Received 31 January 2021 - Accepted 8 November 2021

This is an Open Access article distributed under the terms of the Creative Commons Attribution-Non-Commercial-No Derivatives License (http://creativecommons.org/licenses/by-nc-nd/4.0/), which permits non-comercial re-use and distribution, provided the original work is properly cited, and is not altered or transformed in any way. 


\section{Introduction}

This research describes the structural conditions that allowed the emergence of the biotechnology sector in Chile. If we consider industrial development in Chile during the twentieth century, the year 1973 saw the establishment of a neoliberal system and the 1990s saw the return to democracy. The influence of these historical milestones is very clearly evidenced in the Chilean biotechnology sector. As described in Path's dependency approach "what happened at an earlier point in time will affect the possible outcomes of a sequence of events occurring at a later point in time." (Sewell 1996; 262-263).

This historic process was influenced by global organisations such as the United Nations and the World Bank, which promoted several policies within developing countries. Understanding the process of developing Small and Medium Enterprises (SMEs) is crucial if more of them are to be created in the future, because they have many positive externalities, as well as making countries that possess these technology-based SMEs more globally competitive.

Chilean industrial trends have been strongly influenced by international industrial models. This is due to two aspects. First, these models are linked to a set of funds or credits that allowed their implementation. Secondly, the Chilean government has promoted specific industrial development at different times, based on the mining, agricultural and forestry sectors, among others. However, they have not been permanent, being very dependent on the type of government in power at any given time. Basically, the political sectors, left and right, and their radically different approaches to industrial development.

The first part of this research briefly describes international industrial policies and Chilean industrial development, as a way to provide a historical perspective of the influence on the 
development of biotechnology companies that is described in the second part of this research. Since the 1990s it is possible to observe an important set of public policies that have promoted the development of SMEs. This is relevant for Biotechnology companies, because most of them belong to this group. At the same time, other relevant public policies, were the Innovation and Competitiveness Policies along with the establishment of Chilean clusters. It is thanks to these three pillars in Chilean development since 1990 that the Chilean biotechnology industry has emerged as a relevant sector within the Chilean economy, promoting SMEs, public policies, stakeholders and educational institutions, among others.

\section{Chilean industrial policies and their roots and influence on the development of biotechnology companies}

\subsection{International industrial policies}

To understand the different industrial policies developed within the country, it is necessary to explain what forms of industrialization were promoted by Economic Commission for Latin America and the Caribbean (ECLAC) of United Nation Model in the second part of the twentieth century, the Asian Model of the 1980s, the Washington Consensus of the 1990s, the Increased Washington Consensus of 2000 and the New Structural Economy of 2010. All these global trends from global organisations like the World Bank and the United Nations helped plant the seed of change in countries like Chile along with the idea of focusing on specific aspects of the economy. At the same time, these trends influenced Chilean public policies on innovation and entrepreneurship, encouraging the creation of new companies within the country and consolidating others, such as SMEs. 
In the first half of the twentieth century, Latin American countries followed different paths and it is difficult to detect an industrialisation model in the region. Most of these countries are still importers. However, there are some seeds of industrialisation in Argentina, Brazil, Colombia, Mexico and Chile (Sevares 2010; Benavente et al., 1996).

Since the 1990s, industrial development in Latin America has changed radically influenced by the World Bank trends. It has shifted from a structuralist approach to the approach of the Washington Consensus. This was induced by the Asian development model and its success in the global economy.

Asian countries followed their own development model that was basically based on several aspects such as: the management of high-tech knowledge, the promotion of local entrepreneurship and protectionism policies_-Asian Miracle—(Nelson and Pack 1997).

The Asian Model in the 1980s generated a critical analysis of the structuralist policies promoted by the World Bank from the 1950s to the 1980s. One of the first responses to this criticism came from the institution itself. The Washington Consensus promoted trade liberalisation, privatisation, labour market flexibility and less government regulation. Countries that promoted this approach were able to achieve long-term growth. This was due to the fact that most of these policies required the implementation of a set of controversial policies in the short term. However, according to the promoters of this new paradigm, this set of changes leads to success in the future, despite its lack of clarity in the present (Rodrik 2007).

From this controversial model the New Structural Economy (NSE) has emerged, which promotes both the industrialisation and internationalisation of companies. On the one hand, this model proposes an industrial policy in a market economy as well as the use of comparative 
advantages to succeed. This growth is possible by initially identifying those developed countries that have some similarities of comparative advantage. In this way it is possible to observe success stories, experiences, knowledge transfer and patterns of industrial vitalisation. The next step requires the identification of domestic companies. An economy needs to know if there are already successful companies in some industries or if they need to be fostered. At the same time, the model proposes spontaneous self-discovery by the government-supported private sector, especially in those areas linked to innovation in new industries. In each case, local institutions must define a set of policies such as removing restrictions on quality improvement, promoting improvement, promoting the arrival of companies or incubating programs for new companies. (Lin 2012)

\subsection{Chilean industrial development}

During its history Chile has tried, on several occasions, to be an industrialised country. Historically we can describe four phases: the pre-industrial phase from 1850 to 1929 , the protectionism phase from 1930 to 1950, the industrialisation phase by import substitution (ISI policy) from 1960 to 1970 and the free market phase from the mid-1970s to the present.

During the protectionism phase, Chile, as well as other Latin American countries, adopted the ECLAC Model. In the early years, this model was a continuation of the previous phase of Chilean industrialisation. The ECLAC Model was adopted because, in this period, there was a global concern to link the industrialisation process with the level of development of a country. Among other aspects, ISI's policy involved increasing local production. This surplus production was not absorbed by local demand. This situation forced some Chilean leaders to organise some alliances in the region to increase demand. Asociación Latinoamericana de Libre 
Comercio (ALALC) was one of the first attempts. Some Chilean industrial companies reached consolidation during this period. However, this process of industrialisation was slow and mixed with local political turbulence (Hachette 2003, Turmo and Moslares 2007, Muñoz-Goma 1995). In 1970 another more interesting model emerged within the country, the socialist model. The socialist model controlled industrial production and nationalised the mining sector-copper mining-(Büchi 2008). This model ended with the military coup of 1973.

Chile has followed a model of export-led growth through free markets since the mid-1970s. A radical shift from a socialist economic model to one of an open or neoliberal free market allowed the promotion of industrialisation. In this period, you can observe a series of public policies that had an impact on the Chilean industrialisation process (Clausen 2009). First, the Chilean government created policies that promoted Foreign Direct Investment (FDI) in the country. A significant number of multinational companies were attracted by special tax regulations and the abundance of local natural resources. The presence of these companies in the country boosted industrialisation in two ways. First, these firms brought their own technology to the country and at the same time increased the demand for technological and quality products, and second, the Chilean government lowered its import barriers, allowing for technological modernisation. Chilean companies imported new technology and machinery and at the same time, the abundance of products led to a decrease in local prices. Chilean companies had to deal with this new stage. Both policies, according to the authorities of the time, attracted investment to the country and increased the competitiveness of local companies (Büchi 2008). However, Chilean companies were not adequately prepared to meet this challenge. The Chilean market became very competitive and aggressive, because there were many medium-sized companies and fewer barriers to imports. The 1970s were a difficult period in which some local 
businesses went bankrupt, especially SMEs, while others increased their business competitiveness (Tybout et al. 1991, Alvarez and Vergara 2007).

The Chilean economic model is based on natural resources with an emphasis on efficiency and well-managed production costs (Büchi 2008). From an economy based almost exclusively on the mining and agricultural sectors, in less than 20 years, Chile has developed other sectors such as fruits, wine, forestry and salmon. This model is based on Chile's comparative advantages in these sectors. Each sector was developed through the transfer of technology from foreign countries, foreign investment and the backward and forward linkages absorbed by SMEs. In the 1970s and 1980s, Fundación Chile was responsible for the emergence of new Chilean industries. New technologies, new species (fruits, fish, trees, among others) and new fertilization methods, quality standards and knowledge were imported into the country under this agency's supervision. The adoption of this model showed its first results in the 1990s when Chile experienced significant growth in exports (Ffrench-Davis 2002). ${ }^{1}$

These new sectors needed support and technology to grow. This allowed for the emergence of technology-intensive SMEs within the Chilean market. Several Chilean companies that survived the critical period of the 1970s and many other start-ups belong to this group. The emergence of these companies was not driven by public policy. Technology-intensive Chilean SMEs are entrepreneurial companies that saw the opportunity for success through support for new sectors. From the first moment these new Chilean export sectors developed, technology-

\footnotetext{
${ }^{1}$ Fundación Chile is a private and non-profit organization. His role was especially important as he acted as a technical consultant and disseminator of new technologies, as well as a research and development institution (lizuka 2004). During the 1970s and 1980s it was a government agency.
} 
intensive Chilean SMEs were playing an important role in maintaining efficiency and wellmanaged production costs within these companies.

\subsection{Policies to promote Chilean SMEs}

Since 1973 the neoliberal economic system has promoted a free market. It could be considered as a public policy that promotes free interaction between actors with no external influences. In these terms, industrialisation arises as a natural consequence of this interaction in a world where industrialisation means competitiveness and efficiency. This process evolves from the natural economic forces of competition in a free business ecosystem where companies are able to reach some technological level on their own. Each company, according to its needs, will look for adequate technology and resources to obtain competitive advantages. The role of the state is to maintain the basic conditions of competition in the market. These conditions are created through a modern infrastructure, efficient communications, and information to compete. In this model, industrialisation in a country is a natural consequence of market conditions. Therefore, government economic policies did not pay much attention to SMEs. They were not considered a source of growth. This was because the Chilean economy focused on exporting natural resources, promoting foreign direct investment and establishing large corporations in the country. (Büchi 2008)

This situation changed, in 1990, when the Concertacion (left-wing sector) won Chile's presidential election. In total four consecutive governments of the centre-left coalition came to power: Patricio Aylwin Azocar (1990-1994), Eduardo Frei Ruiz Tagle (1994-2000), Ricardo Lagos Escobar (2000-2006) and Michelle Bachelet Jeria (2006-2010). This was one of the country's most stable periods after 17 years of military dictatorship and therefore, political 
transition was a priority, and this was carried out in an atmosphere of social peace. Economic and social progress during this period achieved a rapid and widespread GDP growth and during the period 1990-1997 the country grew at a rate of $7.6 \%$, to such a level that it positioned Chile at the forefront of Latin America. As a result, profound reforms were carried out to achieve the purpose of growth with equity, although the latter was focused on eradicating poverty, the most relevant was in the area of taxation, especially the increase in income tax and greater labour guarantees. Greater macroeconomic stability was achieved, lowering inflation and balancing State finances, where the Central Bank and international reserves played an important role. Foreign trade increased, import tariffs were lowered and exports were encouraged. The productive sectors that showed the greatest dynamism and in which investment was concentrated were telecommunications, electricity, salmon and fruit exports, as well as copper. As a result of foreign investment, feasibility concessions were developed (Sanfuentes 2021).

After the end of the abovementioned era, Sebatian Piñera Echeñique was elected president together with the Coalición por el cambio (coalition for change) sector, which brought together activists from Renovación Nacional and Unión Demócrata Independiente political parties (right-wing sector). The central government allowed Chile to move forward. The country recovered its capacity to grow (5.3\% average) and at the same time created more than one million jobs, highlighting measures in favour of women's employment such as the 6-month maternity leave after birth and subsidies for women's employment, allowing the country to grow by 576,000 employees.

However, the right-wing sector was unable to consolidate its power, and in 2014 the country once again turned to the left-wing sector with the second government of Michelle Bachelet Jeria, where a series of political reforms were promoted, which together with the Probity and 
Transparency Agenda were the most relevant milestones in this area. In relation to the main economic indicators in this governmental period, growth averaged only $1.8 \%$ over the last four years. Attempts were made to blame this on the international situation, but a comparison with the evolution of both world GDP and that of our trading partners shows that in the last four years the world has continued to grow and it is Chile that has stagnated, with GDP growth barely outstripping population growth. The government argued that the decline in growth was due to mining activity, influenced by the fall in the international price of copper. In this regard, it should be noted that the mining Imacec (Monthly Economic Activity Index) did indeed register a significant decline, from an average annual growth of $1.4 \%$ during the period 2010 2013, to an average of $0.3 \%$ in 2014-2017. However, the non-mining Imacec has also evolved downwards, from an average annual growth of $6 \%$ in the period $2010-2013$, to only $2.1 \%$ during the last four years. (LyD, 2018). In line with this situation, the right regained power in 2017 with Sebastián Piñera Echeñique again as the president (Chile P. d. 2021).

Currently, the Chilean government has a wide range of promotional tools for the development of companies. More than 125 different programs managed by various government institutions have this mission (see table 1). These institutions have an annual budget corresponding to 0.54\% of the Chilean GDP (Chile 2003). These programs are dedicated to supporting Chilean companies, of all sizes, in several areas: technical advice, business development, alliances, training, innovation, technology transfer, financial resources, reorganisation of responsibilities, promotion and internationalisation of exports, environmental management, regional productive development, emerging sectors, specific sectors (manufacturing, agribusiness and fishing), promotion and incubation of entrepreneurship, certification and quality improvement, among many others. This policy has progressively increased the number of companies in the country, 
although it is difficult to assess its impact on SMEs, as these programs do not discriminate by company size (except CORFO and Sercotec). However, no more than $25 \%$ of public resources have been used by SMEs. For this reason, these instruments are continuously reviewed and reformulated by the Chilean government in order to improve their scope (Ferraro and Stumpo 2010, Muñoz-Goma 2007).

TABLE 1. Chilean institutions for the development and promotion of companies

\begin{tabular}{|l|l|}
\hline Ministry & Institutions \\
\hline Ministry of Economy & $\begin{array}{l}\text { Corfo by committees: Innova Chile and InnovaBío- } \\
\text { bío, Sercotec, Sernapesca and INN }\end{array}$ \\
\hline Ministry of Planning and Cooperation & FOSIS (Solidarity and Social Investment) \\
\hline Ministry of Labour & SENCE (National Labor and Training Service) \\
\hline Ministry of Foreign Affairs & ProChile (Export Promotion Agency) \\
\hline Ministry of the Interior & Deputy for Regional Development \\
\hline Ministry of Agriculture & INDAP, SAG and CONAF \\
\hline Ministry of Mining & PAMMA and ENAMI \\
\hline
\end{tabular}

Note: CORFO: Chilean Economic Development Agency; Innova Chile and InnovaBío-bío: Innovation promotion agencies; SERCOTEC: Technical Cooperation Agency; SERNAPESCA: National Fisheries Agency; DCI: National Institute of Norms and Standards; FOSIS: Social Development Agency; SENCE: Agency for the promotion of training; PROCHILE: Export Promotion Agency; INDAP: Agricultural Promotion Agency; CONAF: Forestry Promotion Agency; SAG: Livestock and agricultural promotion agency; PAMMA: Modernization of the agency for the promotion of small-scale mining production; ENAMI: National Agency for Mining Promotion.

Source: Adapted from (Ferraro and Stumpo, 2010).

CORFO has effective programs in the promotion of SMEs. Some of them are: PROFO

(Alliance Promotion Program), PDP (Supplier Development Promotion Program), PTI (Integrated Territorial Development Program), FOCAL (Quality Promotion Program) and FONTEC (Technological Innovation Fund). As of 2005, all these instruments and resources are being gathered under a new institution, the National Innovation Council for Competitiveness (NICC).

2.4. Chilean innovation and competitiveness policies 
The competitiveness of Chilean products and services has been a permanent concern for the last 50 years. During the period of the dictatorship (1973 to 1989) both a leading export economy and a free market economy were implemented. Currently, Chile has a market-oriented economy characterised by a high level of foreign direct investment. This model has generated strong competition between Chilean and foreign companies in the country. This situation has forced an increase in the competitiveness of Chilean companies as a way to survive in this fierce environment (Büchi 2008). Despite the idea that state intervention is not part of a free market model, Chile needs it so that its development has several sources of wealth, not just mining. In this period, a set of prospective studies were carried out to detect these "new sources". During the dictatorship, this task was led by Fundación Chile and CORFO. Once democracy returned, a Science and Technology Program (1992-1995) was implemented as a public policy that promoted productive development (Tybout et al. 1991, Alvarez and Fuentes 2003, Iizuka 2004). This program was financed by the Inter-American Development Bank. This was followed by a second phase (1996-2000) in which a technological innovation program was implemented. As a result of these experiences, the government created a new program focused on SMEs. This new program (Chile INNOVA) identified four areas of interest: ITCs (Information and Communication Technologies), biotechnology, cleaner production and quality. According to this program, Chilean SMEs could compete locally and internationally. MINECON, CORFO, CONICYT, FIA, INN and Fundación Chile participated in this program (2001-2005). In this period the government also detected priority sectors: aquaculture and fisheries, mining, agribusiness, E-learning, ITC industry, tourism, wood industry, renewable energy, steel manufacturing, plastic production, pharmaceutical components and banking. Thus, the Chilean government has developed several public policies in order to promote the competitiveness of 
Chilean companies-Ministry of Economy of Chile, Chilean Agency of Science and Technology, Agrary Innovation Fund, Chilean Normalisation Institute (Patenting and Invention), ITC: Innovation in technology and communications-(Herrera 2001).

In 2005, the National Innovation Council for Competitiveness (NICC) was created. It is an advisory body of the Presidency of the Republic. The purpose of the council is to propose guidelines for a national innovation strategy. The members have the highest level of competence found in the public, scientific, academic and private spheres, thus integrating all the visions required to shape an efficient innovation system and strengthen the efforts made by the country in this sense (Conicyt 2007). This council interacts with many different stakeholders to achieve its goals (see Figure 1). On average, Chile has invested less than $0.5 \%$ of its Gross Domestic Product in research and development (R\&D) over the past 20 years (OECD 2021). As the 2004 figures show, the amount allocated to R\&D in Chile was US\$646 million. 53\% of $\mathrm{R} \& \mathrm{D}$ investment is made by the public sector, $37 \%$ by the private sector and $10 \%$ by other sources. $46 \%$ of these resources are used in R\&D activities carried out by companies, $32 \%$ by universities, $10 \%$ by public bodies and $12 \%$ by private non-profit institutions. $22 \%$ of total resources are currently allocated to basic research and 78\% to applied research and development (Conicyt 2004). 
FIGURE 1. National Innovation Council for Competitiveness and its institutional links

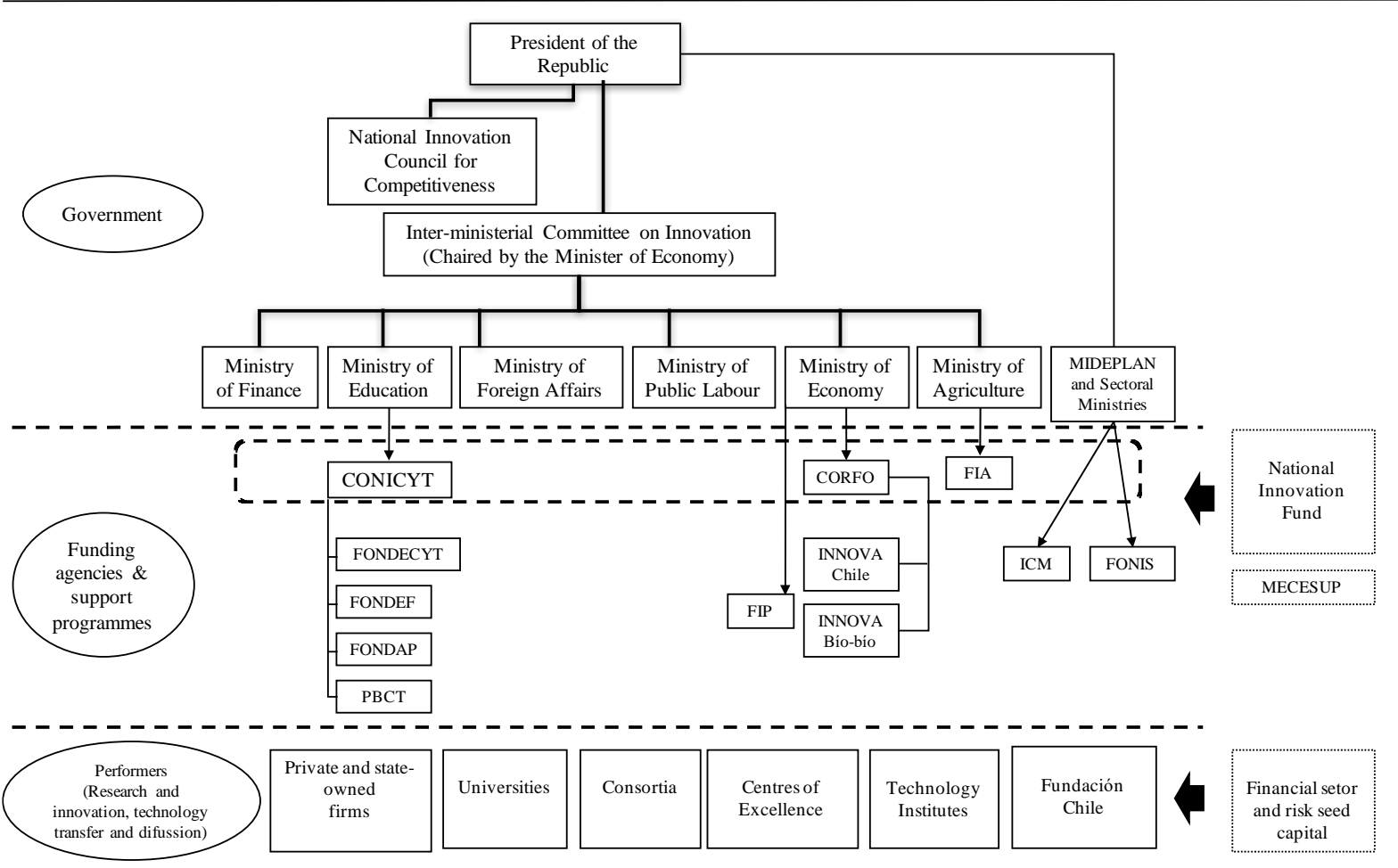

Note: CORFO: Chilean Economic Development Agency; CONICYT: National Commission for Scientific and Technological Research; FIA: Foundation for Agricultural Innovation; FONDECYT: National Fund for Scientific and Technological Development; FONDEF: Fund for the Promotion of Scientific and Technological Development; FONDAP: Fund for Advanced Research in Priority Areas; PBCT: Bicentennial Science and Technology Program; MECESUP: Program to improve the quality of higher education; FIP: Fisheries Research Fund (Ministry of Economy); BWI: Millennium Science Initiative; FONIS: National Fund for Research and Development in Health.

Source: NICC (2008).

\subsection{Chilean clusters}

The Clusters in Chile have emerged as a response to the idea of promoting the development of the country in those areas or sectors of greater economic and social impact by family businesses.

This interest arises from the abundance of limited natural resources exploited in the territory and that somehow give them an added value, a local seal. However, from the beginning these family clusters have relied on the role of the State for funds and financing programs to promote their creation and subsequent growth and development, but over time they have adapted to the 
needs of the market, neglecting the opportunities to develop innovation in other fields. CORFO, for instance, was created with this role (Llorca-Jaña and Miller 2021). However, the low interest in allocating resources, such as in other parts of the world, to a high market focus in the competitive areas of application and investment on $\mathrm{R}+\mathrm{D}+\mathrm{i}$ and a high specialisation in the development and strengthening of the conditions of factors associated with the scientific and technological requirements of these industries have decreased the possibilities of expanding their growth. This has decreased the chances of expanding the market and therefore making biotechnology-based SMEs a niche of possibilities to contribute to the economic growth of the country (Santibanez 2010).

The Chilean State has developed policies that have strengthened, encouraged and financed the emergence of Clusters, including those described below (See Table 2).

TABLE 2. Description of the funds included in the different science, technology and innovation programs

\begin{tabular}{|l|l|}
\hline Program for & Description \\
\hline $\begin{array}{l}\text { National Fund and } \\
\text { Technological and } \\
\text { Productive Development } \\
\text { (FONTEC) }\end{array}$ & $\begin{array}{l}\text { Was aimed at financing technological innovation projects and } \\
\text { associative technology transfer in private companies. }\end{array}$ \\
\hline $\begin{array}{l}\text { Development and } \\
\text { Innovation Fund (FDI) }\end{array}$ & $\begin{array}{l}\text { Promoted initiatives that contributed substantively to generating } \\
\text { and managing technological innovation processes in areas of } \\
\text { strategic impact for the economic and social development of the } \\
\text { country. }\end{array}$ \\
\hline $\begin{array}{l}\text { Fund for the Promotion } \\
\text { of Scientific and } \\
\text { Technological } \\
\begin{array}{l}\text { Development } \\
\text { (FONDEF) }\end{array}\end{array}$ & $\begin{array}{l}\text { Aimed at financing scientific and technological R\&D projects in } \\
\text { universities and technology centres, associated with companies }\end{array}$ \\
\hline $\begin{array}{l}\text { National Fund for } \\
\text { Scientific } \\
\text { Technological } \\
\begin{array}{l}\text { Development } \\
\text { (FONDECYT) }\end{array}\end{array}$ & $\begin{array}{l}\text { Aimed at financing basic research projects presented by national } \\
\text { researchers, without discriminating by theme or scientific } \\
\text { discipline }\end{array}$ \\
\hline $\begin{array}{l}\text { Foundation } \\
\text { Agricultural Innovation } \\
\text { (FIA) }\end{array}$ & $\begin{array}{l}\text { Encourages and promotes the transformation of agriculture and the } \\
\text { rural economy, financing technological innovation and research }\end{array}$ \\
\hline
\end{tabular}




\begin{tabular}{|l|l|}
\hline Program & Description \\
\hline $\begin{array}{l}\text { Mining Research Fund } \\
\text { (FIM) }\end{array}$ & $\begin{array}{l}\text { initiatives aimed at increasing the productivity and competitiveness } \\
\text { of national agriculture. }\end{array}$ \\
\hline $\begin{array}{l}\text { Technical Assistance } \\
\text { related to copper and its by-products. }\end{array}$ & $\begin{array}{l}\text { Supports the contracting of specialised consultancy services in } \\
\text { management areas that contribute to improving the quality and } \\
\text { productivity of companies }\end{array}$ \\
\hline $\begin{array}{l}\text { Supplier Development } \\
\text { Program (PDP) }\end{array}$ & $\begin{array}{l}\text { Supports the integration of supplier companies into production } \\
\text { chains so that they improve and stabilise the commercial link with } \\
\text { their client. This allows SME suppliers to achieve greater levels of } \\
\text { flexibility and adaptability, and the demanding company ensures } \\
\text { the quality of products and/or services in the production chain. }\end{array}$ \\
\hline $\begin{array}{l}\text { Associative } \\
\text { Development Projects } \\
\text { (PROFOS) }\end{array}$ & $\begin{array}{l}\text { Supports the preparation and development of groups of at least five } \\
\text { companies that share a common business idea. This allows them to } \\
\text { share market information and access critical competitive resources } \\
\text { in globalised markets. }\end{array}$ \\
\hline
\end{tabular}

Source: Dini and Stumpo (2011).

These programs have emerged in response to the need to eliminate market imbalance (MunozGoma 1995), which results from a power imbalance. A large number of micro, small and medium-sized enterprises compete with a few large corporations. The latter have high bargaining power, networks, bank financial support and are the owners of Chile's natural resources (copper, productive land, fishing quotas, etc.). For this reason, the NICC supports a study conducted by the Boston Consulting Group in order to define a set of priority areas (see Figure 2). Each of these areas will be promoted according to the cluster development model. These groups are eight: Aquaculture, Processed food for human consumption, Primary agriculture-Fruits, Copper mining and derivatives, Offshoring, Swine and poultry farming, Financial services and Tourism. This policy was partially abandoned in June 2011 due to a return to a classic economic model present in the country prior to 1990. As mentioned above, in an economy based on a free market model, as the Chilean economy currently is, the State is not required to spend resources on the development of specific enterprises. The market itself creates the conditions in which only the best companies survive ("natural selection process"). 
In these terms, the State must support the best companies in the market regardless of their size or the sector to which they belong. The Cluster policy was the main tool of the Chilean NICC. However, the political authorities now consider that the country needs to increase its productivity and improve efficiency. According to them, it is possible to achieve these objectives without concentrating resources. According to the new Chilean political authorities, market imbalances will be eliminated by the "invisible hand" within the Chilean economy. This issue is of great relevance for the biotechnology industry because, if Chile's public policies maintain this long-term policy, it will promote the biotechnology industry as a result of investments and improvements in those sectors that require biotechnology as a way to grow and compete (Cheyre 2011).

Figure 2. BCG/NICC High Potential Cluster Program

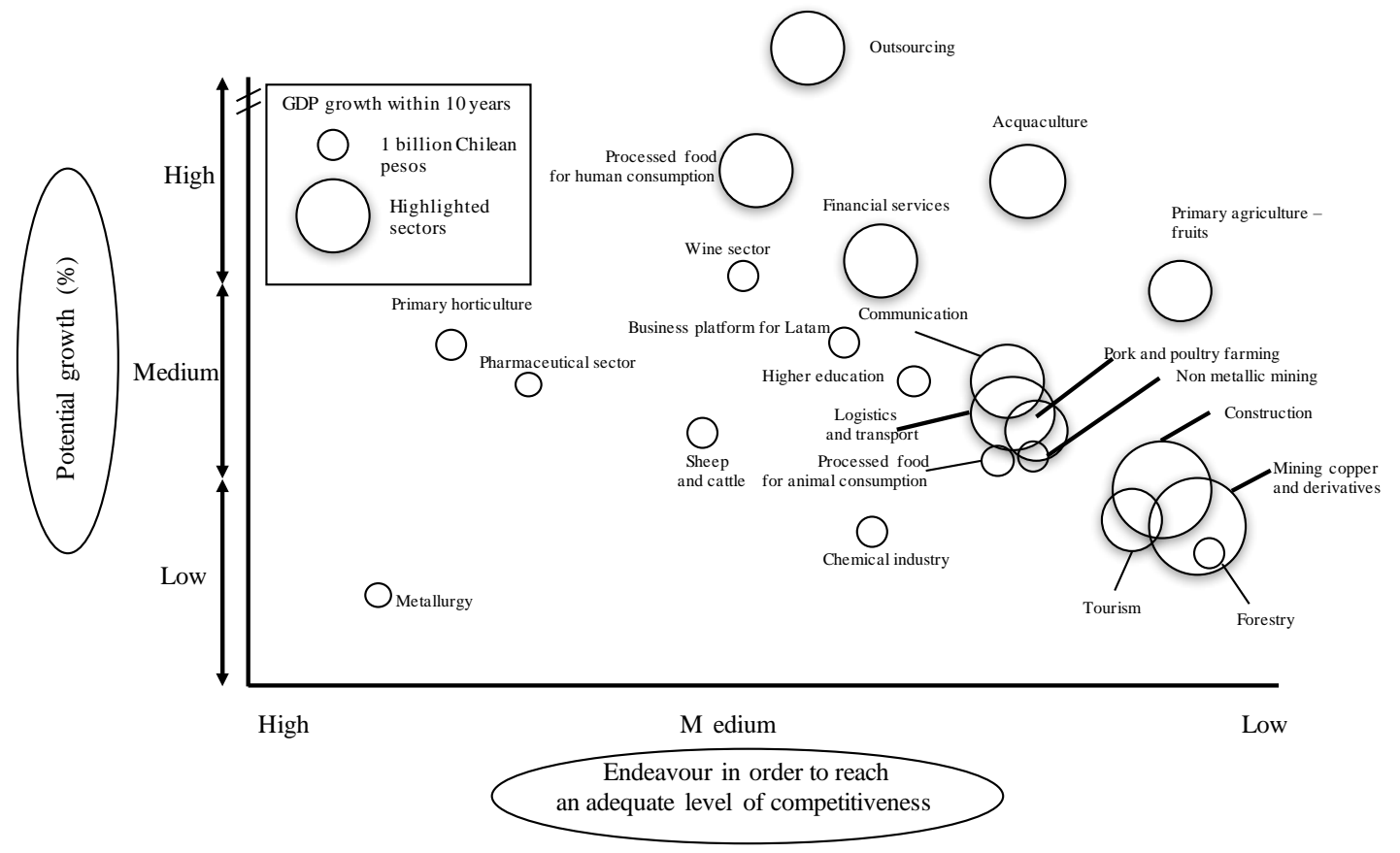

Source: NICC (2008). 
In summary, these public policies led the private sector towards promoting research and investment in the biotechnology sector, thanks to seed capital, the human capital development in universities and the scientific equipment, and thus private companies began to adopt some biotechnological technologies within their traditional methods of production. For instance, the mining sector modernised its process through the adoption of lixiviation (Beckel 2000). Meanwhile, the salmon sector improved the growth of salmon using a new kind of feed along with an analysis of its life cycle and the development of new vaccines for the species (Torres 2007). These examples show the importance and success in the economy of the biotechnology developed by Chilean researchers. For example, the link between SMEs and biotechnology is shown below in Figure 3 using a set of small firms involved in the wine sector, where many of them use biotechnology intensively in several stages of their production processes.

FigURE 3. Wine value chain and its SMEs as Technology-intensive Suppliers and Biotech SMEs

\begin{tabular}{|c|c|c|c|c|c|c|c|}
\hline \multirow{3}{*}{ 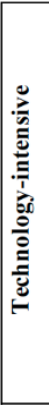 } & 䞨 & $\begin{array}{l}\text { Management information systems } \\
\text { Communuication systems } \\
\text { Water treatment systems } \\
\text { Weather information systems } \\
\text { Phnt desing } \\
\text { Recycling and eco systems production }\end{array}$ & \begin{tabular}{|l|} 
*Biotechnology \\
Gene technology \\
Selection land system \\
Species improvements
\end{tabular} & $\begin{array}{l}\text { "Biotechnology } \\
\text { Rot prevention }\end{array}$ & \multicolumn{2}{|l|}{\begin{tabular}{|l|}
${ }^{*}$ Biotechnology \\
Mature control systems \\
Yeast \\
Quality control systems
\end{tabular}} & \begin{tabular}{|l} 
Marketing services \\
Storage management system \\
Export advising \\
Certification \\
Transport \\
Image producers \\
Legal services
\end{tabular} \\
\hline & 总 & & \begin{tabular}{|l|} 
Wire mesh \\
Fertilizers \\
Spare parts \\
Species
\end{tabular} & Pest control & $\begin{array}{l}\text { Laboratory supplies } \\
\text { Wood chips }\end{array}$ & $\begin{array}{l}\text { Packagging } \\
\text { Containers } \\
\text { Cork } \\
\text { Label } \\
\end{array}$ & \\
\hline & हु. & \begin{tabular}{|l|} 
Laboratory \\
Staimless steel container \\
Staimless steel pipes
\end{tabular} & \begin{tabular}{|l|} 
Agri machinery \\
Tractor \\
Trucks \\
Tools \\
Irigation systems \\
\end{tabular} & $\begin{array}{l}\text { Pest control } \\
\text { spreadings }\end{array}$ & \begin{tabular}{|l|} 
Temperature control equipments \\
Process machinery \\
Enological equipment \\
Stainless steel equipment \\
Mechanical systems
\end{tabular} & $\begin{array}{l}\text { Bottling equipment } \\
\text { Packagging lines } \\
\text { Label machines }\end{array}$ & Refiigerators \\
\hline
\end{tabular}

Source: Torres (2014)

Figure 3 shows the value chain of wine production. As shown, there are 3 main elements (services, supplies and capital) that are composed of a series of elements for wine production. 
At the beginning of the service segment are the communication systems, management system and meteorological system to analyse the conditions in which the vines are to be grown and their grapes later processed and transformed into wine. This starts after having defined the variety of the plant and the production of the necessary ecosystems for the vineyards. At this point, genetic technology selects the best variety of vines and, while they are growing, they are monitored to control pests and other risks with specially developed fertilisers. Once the grapes have developed sufficiently, a check is carried out to define that they are at the exact point of ripeness, after which they are harvested and processed. The resultant wine is stored in a cellar where a team of oenologists together with the mechanical systems define the temperature and date controls for bottling, sealing and labelling, so that the logistics and sales team can then sell and distribute the products. Each of these production phases and associated activities are carried out by technology-based SMEs and within these Biotech SMEs. This is just one example of how these biotech SMEs, which are also present in Chile in the production chains of agriculture, salmon aquaculture, forestry and mining, are composed and interrelated, are relevant in the economy.

\section{Chilean Biotechnology Industry}

Chile is an open economy with strong macroeconomic health. However, in recent years the country has experienced stagnation in its growth due to the concentration of commodity exports and low innovation. This stagnation promotes the growth of the company or the specific growth of the economic sector through private and public effort. In this scenario, one part of society seeks more public support while others are satisfied with the situation. This issue has been in permanent debate without any solution. However, in some specific historical moments, the Chilean government has promoted specific sectors through different public policies with, for 
example, the grouping and the offer of specific public funds. Therefore, it has been considered relevant that this study begins with a historical description as a way of helping to explain the development of the Chilean Biotechnology sector. A historical approach describes how actors, resources, and public policies evolve with respect to specific ever-changing situations. With a historical perspective, it is possible to observe successes and failures under a path-dependent approach. As Pierson $(2004,20)$ mentioned "[dependence on the road] ...refers to dynamic processes involving positive feedback, which generate multiple possible outcomes depending on the particular sequence in which events unfold.". Following this approach, it has been described the history of the Chilean biotechnology sector through the milestones marked by those public policies, resources and actors (both public and private) involved.

Why should a country, whose economy is based on natural resources, be interested in fostering science-based innovation? Currently, this question is easy to answer but difficult to implement. There are two main reasons: the transfer from a natural resource economy to a higher valueadded product economy and, at the same time, reducing production costs and improving productivity (Jimenez 2007).

\section{1. Biotechnology in Chile}

In Chile, biotechnology has been linked to the productive sectors since the early 1950s. In this period the first companies in the veterinary sector emerged, developing their own products thanks to research and innovation. In the 1980s, the first studies emerged from the public sector on the possibility of biotechnology improving various economic sectors such as agriculture, energy, the pharmaceutical industry, mining, waste treatment and the food industry. These initial studies showed that the government was aware of the importance of biotechnology to the 
Chilean economy. In the 1990s, the first public funds were created to improve this sector (see

Figure 4). In 1999 the first diagnosis of this sector emerged. After this study, it was possible to obtain IDB funding for forestry, agriculture and aquaculture. In 2010, an ECLAC research on "Biotechnology cluster, competitive development and governance: the case of Biopolo in Santiago de Chile" was published. It is relevant to mention the various sectors and fields in which biotechnology is used as a way of improving the productivity of the sector, for instance: agriculture, wine industry and mining among others (see Table 3). In addition to the mining and agro-industrial sectors, which have had a cluster policy, these studies have promoted, among government actors, the relevance of the biotechnology sector. However, with the lack of longterm public policies and financial support, this group is an idea without progress (CORFO 1987, Gil, Martínez and Dornberger 2002, Santibáñez 2010).

FIGURE 4: Timeline of the development of the Chilean biotechnology sector

\begin{tabular}{|c|c|c|c|}
\hline $\begin{array}{l}\text { CORFO } \\
\text { INIEC } \\
\text { Studies } \\
(1978)\end{array}$ & & $\begin{array}{c}\text { Science and } \\
\text { Technology } \\
\text { Program } \\
(1992-1996)\end{array}$ & \\
\hline & & $\begin{array}{c}\text { USD 184MM } \\
\text { (BID Fund) }\end{array}$ & $\begin{array}{l}\text { USD 300MM } \\
\text { (Chilean gov.) }\end{array}$ \\
\hline & $\begin{array}{c}\text { Biotech } \\
\text { National } \\
\text { Committee } \\
\text { (CONICYT) } \\
(1983)\end{array}$ & & $\begin{array}{c}\text { Technological } \\
\text { innovation } \\
\text { program } \\
\text { Phase I } \\
(1996-2000)\end{array}$ \\
\hline
\end{tabular}

Source: developed for this study 
TABLE 3. Main fields of biotechnology application in Chile

Mining: copper and other mining

Biomass, bioleaching.

Food industry

Agricultural and Agro-industrial

Fruits for export

Horticulture

Processed foods

Wine industry

Genetic improvement assisted by molecular markers.

Molecular diagnosis.

Value addition and differentiation with the use of biotechnologies.

Bioprocesses.

Food industry

Livestock

Poultry

Pigs

Ovine

Bovine

Milk

Aquaculture

Salmon farming
Animal health: vaccines, immunostimulants, others.

Genetics and reproduction.

Animal feed.

Forestry: forest plantations and pulp

Genetic improvement assisted by molecular markers.

Pest and disease control.

Bioprocesses.

\section{Energy}

Unconventional renewable energy based on the use of biomass.

Environment

Bioremediation.

Treatment of organic waste

Health

Study of pathologies of greater prevalence in Chile in terms of therapies.

Molecular diagnosis, and

Vaccines.

Source: Santibáñez (2010).

Despite the concentration of companies in Chile's Metropolitan Region, those sectors based on natural resources promote regional growth, competitive improvement (Gil, Martínez and Dornberger 2002), and attract foreign direct investment in specific biotechnology sectors (Santibáñez 2010).

During 2016, CORFO launched the Initiative for Integrated Strategic Development in Biotechnology, dedicated to coordinating the set of capacities installed within companies, public bodies and investment networks. This initiative has a group of actors: ASEMBIO, AMCHAM, Fundación Imagen de Chile, Programa Ganesha Lab, Direcon and Prochile, 
Iniciativa científica milenio (Minecon), Inapi, etc. It is based on a set of strategic axes (IFI-E) and promotes three pillars:

1. Promotion of innovation and biotechnological entrepreneurship:

- Creating a coordinated ecosystem in innovation and biotechnological entrepreneurship:

- Promoting international networks that foster international links with local companies

- Facilitating the expansion of local biotechnological developments

2. Generation of suitable conditions for the growth of the biotechnology industry:

- Controlling local regulation to avoid barriers that are an obstacle to biotechnological products and services

- Understanding international regulations in foreign markets that demand Chilean biotech products

3. Complete value chains for some incomplete products/services in order to promote their market launch

In terms of public funds, there is no clear relationship between the way a country organizes its financial development system and the performance of biotechnology. The causes of this lie in the diversity of success factors that influence biotechnological research and application. This also applies to knowledge and discoveries, the transfer of knowledge between academia and business, the strengthening of innovation and product development, as well as the facilitation of access to finance and coordination at the national and international levels (Enzing 2007).

\subsection{Chilean ecosystem of innovation in biotechnology}

Since the 1990s Chile has promoted several public policies in this ecosystem. Within this ecosystem it is possible to identify several actors: institutions, public and private companies, organisations, research centres, consortia, business incubators and "angel" investors. From their interaction, it has been possible to identify this specific sector as one that interacts well with all other Chilean economic sectors (see Figure 5). 
FiguRE 5. Actors in Chilean biotechnology

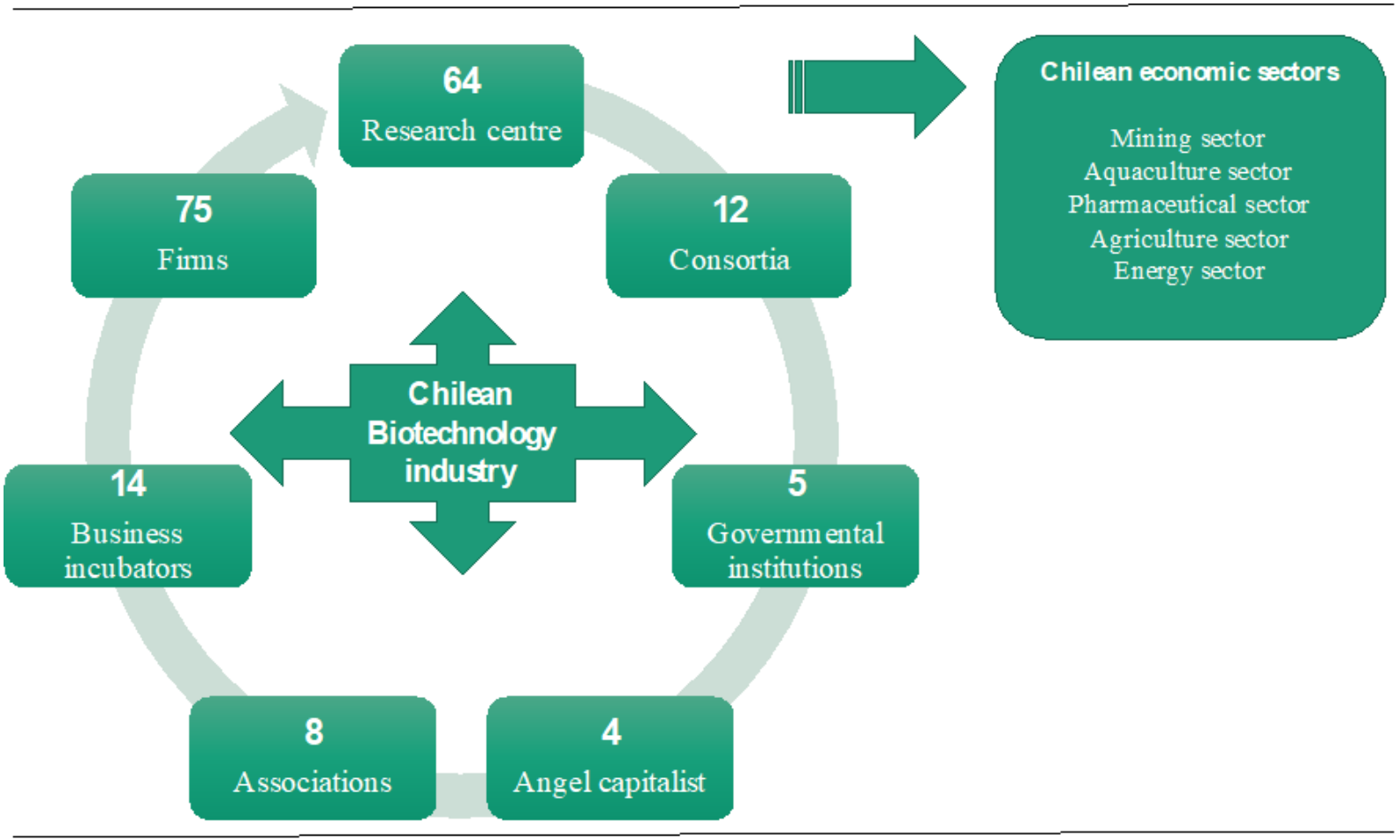

Source: Preparation for this study based on data from www.redbioinnova.com

The most recent public policies in the sector give a different picture (see Figure 6). Since 2015 CORFO led the IFIe Biotech, this integrative promotion initiative focused on biotechnology, in order to detect the main gaps in the sector and develop a strategy for it until 2030. From this initiative a Translational Biotechnology Platform has emerged as a catalyst and to promote ecosystem institutions with the main objective of scaling and internationalising Chilean biotechnological products. CORFO is currently investing in this Chilean Biotechnology Strategy 2030 but the Coronavirus pandemic crisis has reduced the effort and investment in this strategy. 
FIGURE 6. Chilean biotechnology ecosystem

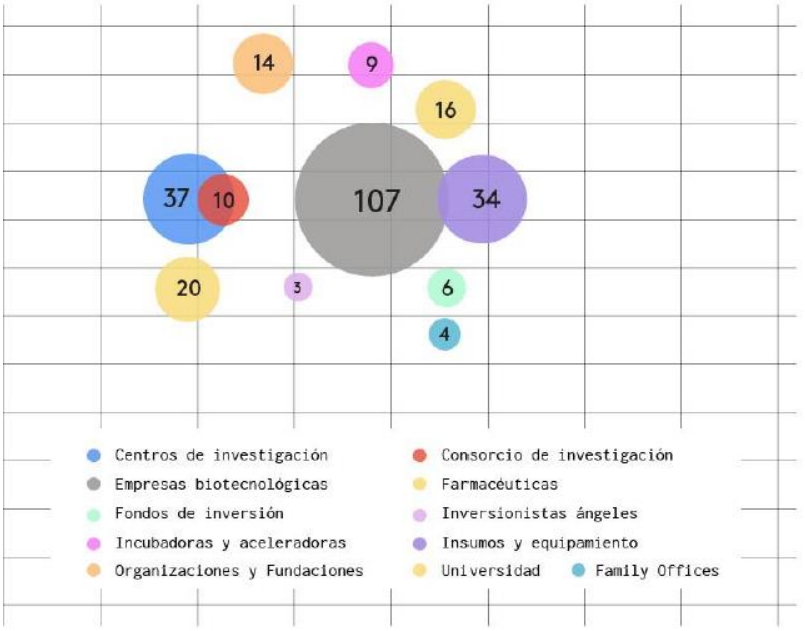

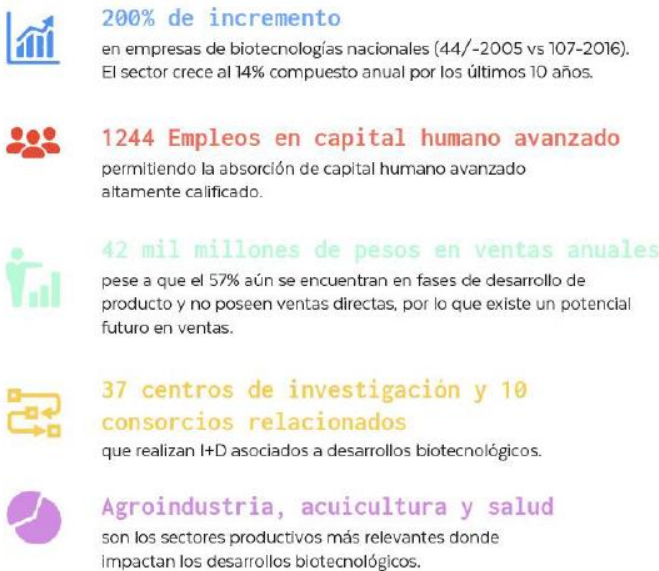

Source: CORFO IFI Biotechnology (2018)

\subsection{Organizations and institutions}

According to Red Bio Innova, a Chilean private association focused on the development of the biotechnology sector, the Chilean innovation ecosystem is composed of 64 research centres, 12 consortia, 5 government institutions, 4 angel investors, 8 associations and 14 business incubators, with most of them located in the Metropolitan Region of Chile (Capital City). From their interrelationship, a consolidated set of companies, research and development and innovations in this industry have emerged.

\subsection{Chilean biotechnology companies}

A biotechnology company uses modern (unconventional) biological techniques in technologies or commercial product development. Fermentation companies (production of beer, wine, cheese, yeast, sausages, etc.) are excluded from this definition. They are excluded because these companies incorporate modern biotechnology into the production process. Chilean biotechnology companies are classified into four groups (see Table 4). Within these categories, 
there are companies linked to biotechnology since the 1960s. Different types of companies, supplying different sectors, are created by biologists, veterinarians, chemists and doctors who have graduated from the two largest universities in the country, Pontificia Universidad Catholica de Chile and Universidad de Chile. They were entrepreneurs in areas barely developed as a business within the country at that time. Currently, there are few cases that have survived but they are very successful. Most of them are family SMEs, while others emerged from individual initiatives or university spin-offs. Most of them are under the age of 30, while spin-offs are usually less than 10 years old. In 2009 there were around 200 companies and research centres linked to biotechnology. Currently this number is maintained, despite the lack of strong public policies focused on the sector. Since 2010, Chile has shown a lack of public policies aimed at investment in R\&D has a whole (EY 2016, Gil, Martínez and Dornberger 2002).

TABLE 4. Types of Chilean biotechnology companies

\begin{tabular}{ll}
\hline Category & Description \\
\hline Type I & $\begin{array}{l}\text { Company that develops advanced biotechnological products and/or processes, } \\
\text { conducts research and development and markets products or services by itself } \\
\text { or through other biotechnology companies }\end{array}$ \\
\hline Type II & $\begin{array}{l}\text { Company that has sporadically developed a biotechnological product and/or } \\
\text { process (non-permanent innovative process), that carries out R\&D (or has funds } \\
\text { for it) and that mainly markets products of other companies }\end{array}$
\end{tabular}

\begin{tabular}{ll}
\hline Type III & $\begin{array}{l}\text { Company that has its own funds and/or carries out R\&D to incorporate or adapt } \\
\text { processes in its production chain (its final products are traditional) }\end{array}$ \\
\hline Type IV & $\begin{array}{l}\text { Company that sells biotech products (but does not conduct research and } \\
\text { development) }\end{array}$ \\
\hline
\end{tabular}

Source: Gil, Martínez and Dornberger (2002).

The Chilean biotech industry is a very small global player. According to the 2016 EY Biotechnology Report, US and European biotech companies generated revenue of US\$132.7 billion and employed 203,850 people (EY 2016). Chilean biotechnology companies generated 
sales of US\$9.2 million and employed 420 people. According to cost of sales estimates, these companies generated $0.003 \%$ of Chilean GDP in 2015. Despite this small figure, this sector grew to 57 companies, representing an increase of 90\% over 2002 (30 companies). Modern biotechnology is characterized by long cycles of product, technology and market insecurity (rapid changes, technological leaps), as well as being capital intensive. This makes it difficult to form new companies within the sector. However, spin-offs of private and public universities appear to be the new source of growth among biotech companies. Of these companies in 2006, only 17 survived until 2015, signifying a 57\% survival rate. This rate is positive considering the main limitations for the development of the biotechnology industry in Chile (Gil, Martínez and Dornberger 2002, Santibáñez 2010):

- The low availability of funding for scaling up and implementation.

- Incentives are not aimed at creating innovation: state subsidies for R\&D far exceed subsidies for the transfer, scaling and implementation of R\&D. Innovations. (hundreds of thousands vs. tens of thousands of Chilean pesos). This is compounded by the incipient development of the venture capital industry.

- The low activity of national and international patenting both $\mathrm{R}+\mathrm{D}+\mathrm{i}$ taking into account the existing potential.

- The low comparative percentage (11.9\%) of employees with doctorates in Chilean biotechnology companies.

- Regulatory limitations on the use of genetically modified organisms.

- Low investment in R\&D\&I of national companies that use biotechnology.

Some companies have been able to export and open branches in foreign markets, especially in South America. According to these firms, they have grown more than Chilean non-exporting biotechnology companies (Gil, Martínez and Dornberger 2002).

In 2007, as a result of the technological idea of building and maintaining large bodies of water at low cost, the company Crystal Lagoons was established. This company has grown 
unexpectedly for its founder Fernando Fischmann, who always wanted to find a way to maintain large volumes of crystalline, turquoise water resembling that found in the Caribbean. His training as a biochemist led him to develop the technology to filter large quantities of water and as a result he built his first artificial lagoon in San Alfonso del Mar in Algarrobo, Chile. The lagoon was $1 \mathrm{~km}$ in length, covered 8 hectares and contained 250 million litres of water. For several years it held the record for the largest swimming pool on the planet. Currently the company develops projects all over the world in countries such as Colombia, Brazil, Dubai, Australia, Egypt, Indonesia, among others. It has more than 10 offices around the world and close to 300 urban, tourist, public and industrial projects worldwide. For this biotech company, innovation is the cornerstone, and the company states that this concept is in the core of the organisation and has allowed Crystal Lagoons to constantly develop new technologies, beyond just crystalline lagoons. Fernando Fichmann points out that constant innovation is possible because Crystal Lagoons invests around 30\% of its cash flow in R\&D. The organisation notes that history has shown that countries that depend mostly on the export of raw materials for their economy, lag in innovation. However, it is important to note that a country's high level of development and quality of life are closely linked to innovation (Yañez 2016). This successful case shows the possibilities within the sector. Nevertheless, Chile is still dependent on research and development from other countries, although we have installed capacity within the country, and it still requires long-term public policies beyond a presidential term (4 years). According to the diagnosis made in 2019 by Troncoso Chile has a Biotechnology Innovation System (BIS), composed of 256 private institutions and 8 public institutions (Troncoso, 2019). This represents a framework where Chilean biotechnology could emerge as a mature and consolidated industry after decades of effort. At the same time, this study shows a set of difficulties and lack of 
relevant results in the market, similar to the findings of our research. It is relevant to emphasize the lack of a public policy towards industrial development as the main reason for the technological dependence.

\section{Conclusions}

This study has described the historical conditions, and how Chilean biotechnology SMEs have been able to create a sector within the Chilean economy. From the analysis of secondary data, it has been possible to describe the emergence of this type of companies within the Chilean economy. This analysis shows the link between structural conditions and appropriate public policies, which means that these companies do not arise by chance. Understanding their development process is crucial to be able to promote the creation of more of these technologybased SMEs, because they have many positive externalities in addition to being more competitive worldwide (Kantis et al. 2020).

All companies require a business ecosystem and a set of internal conditions that promote their development and successful performance. This is true for companies, but especially for biotech companies, because the limitations they face are extremely difficult to overcome. We have described an innovative ecosystem and the Chilean conditions necessary to promote the biotechnology industry. This shows positives and negatives, but biotechnological entrepreneurship is developing despite many limitations. A country with little scientific promotion like Chile tends to import all kinds of industrial inputs. This promotes a high local demand for biotechnological products and services. If this technological advance promoted by biotechnology occurs locally, this leads to a decrease in the cost of imports, promotes better after-sales services and helps solving problems at the local level. However, in the case of the 
biotechnology sector, industrial policies have been successful taking into account the competitiveness and prevalence of biotechnology companies in the economy (Judice and Baeta 2007).

\section{Aknowledgments}

This research has been possible through financial support from VRIDEI at USACH, Universidad de Santiago de Chile. Research Project Nro. 031860TZ.

\section{References}

Alvarez, Rodrigo and Rodrigo Fuentes. 2003. "Trade Reforms and Manufacturing Industry in Chile." Working Paper Central Bank of Chile 210.

Alvarez, Rodrigo and Sebastián Vergara. 2007. "Sobrevivencia de las PyMEs en Chile.” Estudios Públicos 107: 79-98.

Benavente, José Miguel, Gustavo Crespi, Jorge Katz and Giovanni Stumpo. 1996. "La transformación del desarrollo industrial de América Latina." ECLAC Review 60: 49-72.

Beckel, Jorge. 2000. El proceso hidrometalúrgico de lixiviación en pilas y el desarrollo de la minería cuprífera en Chile. Santiago de Chile: CEPAL. Serie Desarrollo productivo 79.

Büchi, Hernán. 2008. La Transformación Económica de Chile: el Modelo del Progreso. Santiago de Chile: El Mercurio-Aguilar.

Cheyre, Hernán. 2011. "Política industrial no discriminatoria.” La Tercera Digital. Accessed July 7. https://www.latercera.com/noticia/politica-industrial-no-discriminatoria/.

Chile, Gobierno de. 2003. Comisión Nacional para el desarrollo de la biotecnología. Santiago de Chile: Gobierno de Chile.

Chile, Presidencia de. 2021. "Gobierno de Chile." Accessed October 2. https://www.gob.cl/instituciones/presidencia/

Clausen, Bianca. 2009. Untersuchungen zur Wirschaftspolitik, Exchange rate uncertainty,investment and International trade. Köln: Institute für wirschaftspolitik.

Conicyt. 2004. Estimación del Gasto en Investigación y Desarrollo en Chile. Santiago de Chile: Conicyt Chilean Government.

Conicyt. 2007. El sector vitivinícola en Chile. Capacidades de investigación y áreas de desarrollo 
científico-tecnológico. Santiago de Chile: Conicyt Chilean Government.

CORFO. 1987. Investigación de la Biotecnología para su aplicación en el país: Resumen. Santiago de Chile: Gerencia de Desarrollo-Área agrícola. Chilean government.

CORFO IFI. 2018. Propuesta: Estrategia de Biotecnología al 2030. Iniciativa de Fomento Integrada Estratégica en Biotecnología. Santiago de Chile: CORFO.

Dini, Marco and Giovanni Stumpo. 2011. Políticas para la innovación en las pequeñas y medianas empresas en América Latina. Santiago de Chile: Naciones Unidas, CEPAL.

Enzing, Christien, coord. 2007. BioPolis. Inventory and analysis of national public policies that stimulate biotechnology research, its exploitation and commercialization by industry in Europe in the period 2002-2005. https://op.europa.eu/en/publication-detail/-/publication/8d0dcc9a-6ef94dcf-8cf7-7c2ebdf81d4c.

EY. 2016. Biotechnology Report 2016: Beyond borders. Returning to earth. EY.

Ferraro, Carlo and Giovanni Stumpo. 2010. Políticas de Apoyo a las Pymes en América Latina: Avances Innovadores y Desafios Institucionales. Santiago de Chile: ECLAC Book.

Ffrench-Davis, Ricardo. 2002. "El impacto de las exportaciones sobre el crecimiento de Chile", Revista de la CEPAL 76: 143-160.

Gil, Lionel, Víctor Martinez and Utz Dornberger. 2002. Caracterización de la industria biotecnológica chilena. Santiago de Chile: CORFO, Chilean government.

Hachette, Dominique. 2003. "Chile: apertura comercial amplia y variada" Paper presented at Séminaire EMMA-RINOS, Analyse comparatiste des processus d'intégration régionale Nord-Sud, Paris, France, May 26-27.

Herrera, Gustavo. 2001. Chile INNOVA 2001-2006. Santiago de Chile: Ministry of Economy of Chile. Iizuka, Michiko. 2004. "Organizational capability and export performance: the salmon industry in Chile" Paper presented at DRUID Winter Conference, Elsinore, Danmark, January 22-24.

Jimenez, Oscar. 2007. "Biotecnología: un factor de competitividad para la economía chilena. Visión estratégica desde la perspectiva de la atracción de inversiones a Chile”. In Gestión - Innovación y comercialización en biotecnología, edited by Lionel Gil, and Marta Adonis, 245-267. Santiago de Chile: Editorial Universitaria.

Judice, Valeria and Adelaide Baeta. 2007. "Gestión de la innovación y factores de competitividad en la Bioindustria.” In Globalización, acumulación de capacidades e innovación, edited by Gabriela Dutrenit, Javier Jasso and Daniel Villavicencio, 180-200. México: Fondo de Cultura Económica. Kantis, Hugo, Juan Federico, Sabrina Ibarra and Cristina Fernandez. 2020. Indice de Condiciones Sistémicas para el Emprendimiento Dinámico. General Sarmiento: Prodem.

Lin, Justin. 2012. New Structural Economics. Washington: The World Bank. 
Llorca-Jana, Manuel and Rory Miller. 2021. Historia Economica de Chile, desde la Independencia. Santiago de Chile: Ril Editores.

LyD. 2018. "Hora de balances: Segundo mandato de Michelle Bachelet." TEMAS PÚBLICOS 2: 1-8.

Muñoz-Gomá, Oscar. 1995. Los Inesperados Caminos de la Modernización Económica. Santiago de Chile: Instituto de Estudios Avanzados.

Muñoz-Gomá, Oscar. 2007. El Modelo Económico de la Concertación 1990-2005: ¿Reformas o Cambio? Santiago de Chile: Catalonia.

Nelson, Richard and Howard Pack. 1997. The Asian Miracle and Modern Growth Theory. Pennsylvania: University of Pennsylvania and The World Bank.

NICC. 2008. Toward a Cohesive and Well Governed National Innovation System. Santiago de Chile: Document elaborated by World Bank for National Innovation Council for Competitiveness. Chilean government.

OECD. 2021. Gross domestic spending on $R \& D$. Accessed December 24. doi: 10.1787/d8b068b4-en.

Pierson, Paul. 2004. Politics in time: History, institutions and social analysis. Princeton and Oxford: Princeton University Press.

Rodrik, Danny. One Economics, many recipes. Globalization, Institutions and Economic Growth. Princeton: Princeton University Press, 2007)

Sanfuentes, Andrés. 2021. "Progresos en los gobiernos de a Concertación.” El Mostrador. Accessed August 9. https://www.elmostrador.cl/destacado/2021/08/09/progresos-en-los-gobiernos-de-laconcertacion/

Santibáñez, Edgardo. 2010. Desarrollo competitivo de un clúster biotecnológico: El Biopolo de Santiago. Volumen II. Competitividad nacional y regional para el desarrollo de la industria de la biotecnología en Chile. Santiago de Chile: ECLAC.

Sevares, Julio. 2010. ¿Por qué crecieron los países que crecieron? Buenos Aires: Edhasa.

Sewell, William. 1996. "Three temporalities: Toward and eventful sociology." In The Historic Turn in the Human Sciences, edited by Terrance McDonald, 248-280. Ann Arbor: University of Michigan Press.

Torres, Carlos. 2007. "Desarrollo de proveedores en la salmonicultura chilena." Journal of Technology Managment Innovation 2(1): 92-107.

Torres, Isabel. 2008. "SME's internationalization process: The case of Chilean Technology-intensive Suppliers (TiS)" PhD diss., University of Leipzig, Germany.

Turmo Garuz, Joaquín and Carlos Moslares García. 2007. "Chile. De la industrialización mediante sustitución de importaciones a la liberalización y diversificación comercial." Boletín Económico del ICE 2914: 49-62. 


\section{Journal of Evolutionary Studies in Business}

Troncoso, Pablo, 2919. "El rol de la industria biotecnológica en la sofisticación y diversificación de la matriz productiva chilena: dificultades y propuestas para su desarrollo.”, MSc diss., Universidad de Chile.

Tybout, James, Jaime De Melo and Vittorio Corbo. 1991. "The effects of trade reforms on scale and technical efficiency: New evidence from Chile.” Journal of International Economics 3: 231-250.

Yañez, Cecilia. 2016. "La Clave del éxito tras Crystal Lagoons." La Tercera. Accessed July, 6. https://www.latercera.com/noticia/la-clave-del-exito-tras-crystal-lagoons/ 